\title{
Mikrobiyoloji Laboratuvarlarında Çalışan Güvenliği ve Biyogüvenlik Uygulamaları Açısından Türkiye'de Çok Merkezli Bir Değerlendirme
}

\section{Employee Safety and Biosafety Applications in Microbiology Laboratories; A Multicenter Evaluation in Turkey}

\author{
Mehmet KÖROĞLU ${ }^{1}(I D)$, Selma ALTINDiş²(ID), Özlem AYDEMIR ${ }^{1}(I D)$, Büşra YÜKSEL ${ }^{1}(I D)$, \\ Tayfur DEMiRAY ${ }^{3}(I D)$, Ünal ERKORKMAZ4 (ID), Ferhat Gürkan $\operatorname{ASLAN}^{5}\left(\right.$ ID), Barış $\operatorname{OTLU}^{6}(I D)$, \\ Mustafa ALTINDiş ${ }^{1}$ (ID), LabBioSafety TR Çalışma Grubu* \\ ${ }^{1}$ Sakarya Üniversitesi Tıp Fakültesi, Tıbbi Mikrobiyoloji Anabilim Dalı, Sakarya. \\ 1 Sakarya University Faculty of Medicine, Department of Medical Microbiology, Sakarya, Turkey. \\ 2 Sakarya Üniversitesi İşletme Fakültesi, Sağlık Kurumları Yönetimi, Sakarya. \\ 2 Sakarya University Faculty of Management, Healthcare Administration, Sakarya, Turkey. \\ ${ }^{3}$ Sakarya Üniversitesi Eğitim ve Araştırma Hastanesi, Klinik Mikrobiyoloji Laboratuvarı, Sakarya. \\ 3 Sakarya University Training and Research Hospital, Clinical Microbiology Laboratory, Sakarya, Turkey. \\ ${ }^{4}$ Sakarya Üniversitesi Tıp Fakültesi, Biyoistatistik Anabilim Dalı, Sakarya. \\ ${ }^{4}$ Sakarya University Faculty of Medicine, Department of Biostatistics, Sakarya, Turkey. \\ ${ }^{5}$ Fatih Sultan Mehmet Eğitim ve Araştırma Hastanesi, Klinik Mikrobiyoloji Laboratuvarı, İstanbul. \\ ${ }^{5}$ Fatih Sultan Mehmet Training and Research Hospital, Clinical Microbiology Laboratory, Istanbul, Turkey. \\ ${ }^{6}$ İnönü Üniversitesi Tıp Fakültesi, Tıbbi Mikrobiyoloji Anabilim Dalı, Malatya. \\ ${ }^{6}$ Inonu University Faculty of Medicine, Department of Medical Microbiology, Malatya, Turkey. \\ * LabBioSafety TR Çalışma Grubu (* İsme göre alfabetik olarak sıralanmıştır.) Ali Özer, Ayşe Ertürk, Canan Külah, \\ Devrim Dündar, Emel Uzunoğlu, Ergenekon Karagöz, Figen Öztürk, Fikriye Milletli Sezgin, Gönül Aslan, Gül Durmaz, \\ Hakan Uslu, Hüseyin Güdücüoğlu, İdris Şahin, Mehmet Özdemir, Mehmet Sinan Dal, Muhammet Güzel Kurtoğlu, \\ Nevzat Ünal, Nezahat Akpolat, Rukiye Berkem, Sebahat Aksaray, Selami Günal, Sevin Kırdar, Yeliz Çetinkol.
}

Makale Atıfı: Köroğlu M, Altındiş S, Aydemir Ö, Yüksel B, Demiray T, Erkorkmaz Ü ve ark. Mikrobiyoloji laboratuvarlarında çalışan güvenliği ve biyogüvenlik uygulamaları açııından Türkiye'de çok merkezli bir değerlendirme. Mikrobiyol Bul 2020;54(3):347-367.

\section{ÖZ}

Tıbbi laboratuvar çalışanları, rutin aktiviteleri esnasında başta biyolojik ve kimyasal olmak üzere çeşitli tehlikelere maruz kalabilmektedirler. Ülke genelini yansıtabilecek olan bu çok merkezli çalışmada; tıbbi mikrobiyoloji laboratuvarlarında, çalışan güvenliği ile biyogüvenlik uygulamalarının belirlenmesi ve mevcut durumun ortaya konulması amaçlanmıştır. Farklı illerden 23 hastanenin (14 tıp fakültesi hastanesi, yedi eğitim ve araştırma hastanesi, iki devlet hastanesi) tıbbi mikrobiyoloji laboratuvarında çalışan toplam 1072 personele çalışan güvenliği ve biyogüvenlik uygulamaları ile ilgili kurallar, görüşler, tutum ve davranışları sorgulayan 33 sorudan oluşan bir anket uygulanmıştır. Kurumlar, yaş grupları, cinsiyet, eğitim durumu, çalışma süreleri ve meslek grupları ile biyolojik ve kimyasal tehlikelere maruziyet açısından istatistiksel analiz yapılmıştır. Üniversite/eğitim ve araştırma hastanelerinde yaklaşık \%50, devlet hastanelerinde yaklaşık \%70 oranında laboratuvar içerisinde yiyecek ve içecek tüketildiği belirlenmiştir $(p<0.05)$. Diğer kurumlarla karşılaştıııldığında devlet hastanelerinde; ayrı bir dinlenme odası olmadığı (\%35), personelin kendi bilgi ve uygulamalarını yetersiz (\%28.9) bulduğu, laboratuvar önlüklerinin yüksek oranda (\%95) 
evde yıkandığı, eğitim düzenlenme ve katılım oranları (\%90) ile personelin tıbbi atık bilgi düzeylerinin daha yüksek olduğu anlaşılmışır ( $p<0.05$ ). Yaş ilerledikçe; eğitim alma, laboratuvarda yiyecek ve içecek tüketimi, koruyucu ekipmanlarla (önlük, eldiven ve maske) laboratuvar dışına çıkmama, laboratuvar kaynaklı enfeksiyon geçirmiş olma oranı artmıştır $(p<0.05)$. Genç yaş grubunda önlükleri evde yıkama, ileri yaş grubunda ise hastanede yıkama daha yüksek orandadır $(p<0.05)$. Laboratuvar içerisinde yiyecek ve içecek tüketimi konusunda cinsiyete göre anlamlı bir fark bulunmamıştır $(p=0.09)$. Her iki cinsiyette de $1 / 3$ oranında periyodik sağlık kontrollerinin yaptırımadığı ve erkeklerde eldiven kullanımı ile tıbbi atık kurallarına uyumun daha düşük olduğu belirlenmiştir. Kadın çalışanlar, bilgi ve uygulamalar konusunda kendilerini daha yetersiz görmektedir $(p<0.05)$. Periyodik kontrollerini düzenli aralıklarla yaptırmayanların oranı, lise ve yüksek lisans grubunda daha yüksektir. Tıbbi atık kurallarına uyum ilköğretim düzeyinde daha düşük bulunmuştur. Laboratuvar ortamında yiyecek ve içecek tüketimi; ilköğretim ve lise düzeyinde en yüksek iken, yüksek lisans ve doktora/uzmanlık düzeyinde en düşük orandadır $(p<0.05)$. Uzman hekimler, laboratuvar teknisyenleri ve hizmet süresi fazla olanlar, daha yüksek oranda sağlık kontrollerini yaptırmaktadır $(p<0.05)$. Koruyucu ekipmanla laboratuvar dışına çıkmama kuralına meslekte $>35$ yıl çalışan grubunda tam uyulduğu, diğer gruplarda \%70-85 oranında uyum olduğu görülmüştür $(p<0.05)$. Hepatit B aşısı yaptırma oranı; uzman hekimlerde en yüksek, temizlik ve diğer personel grubunda ise en düşüktür $(p<0.05)$. Temizlik personeli grubunda tıbbi atık kurallarına uymama daha yüksek oranda gözlenmiştir $(p<0.05)$. Sonuç olarak; son yıllarda ülkemizde tıbbi mikrobiyoloji laboratuvarlarında çalışan güvenliği uygulamalarında ilerlemeler katedilmiş olmasına rağmen, henüz yeterli düzeyde olmadığı saptanmıştır. Sonuçlar, ülkemizdeki tıbbi laboratuvarların genel profilini de dolaylı olarak yansıtmaktadır. Fiziki mekan ve ekipman eksiklikleri giderilmeli, personelin periyodik sağlık kontrolleri ve aşılanmaları sağlanmalı, laboratuvara ilgisiz kişilerin girişi engellenmeli, laboratuvar ortamında yiyecek/içecek ve sigara tüketimi engellenmeli, laboratuvar önlüklerinin hastanede yıkanması sağlanmalı, tıbbi atık eğitimi dahil hizmet içi eğitimler yapılmalı ve bu eğitimler davranış değişikliği sağlayacak mekanizmalarla geliştirilmelidir.

Anahtar kelimeler: Biyogüvenlik; çalışan; laboratuvarlar

\section{ABSTRACT}

Medical laboratory personnel may be exposed to various hazards, especially biological and chemical, during their routine activities. In this multicenter study, which could reflect the nation wide results, it was aimed to determine the safety and biosecurity practices of the employee working in medical microbiology laboratories and to reveal the current situation. A total of 1072 personnel working in the Medical Microbiology Laboratory of 23 hospitals (14 medical faculty hospitals, seven ministry of health training and research hospitals and two state hospitals) from different provinces were provided with a questionnaire consisting of 33 questions inquiring about the rules, opinions, attitudes and behaviors regarding safety and biosafety practices. Statistical analyses were made with institutions, age groups, gender, educational background, working time and occupational groups in terms of exposure to biological and chemical hazards. It was determined that approximately $50 \%$ personnel of the university/ training and research hospitals and $2 / 3$ of the state hospitals personnel consumed food and beverages in the laboratories $(p<0.05)$. Compared with other hospitals, it was determined that in state hospitals; the absence of separate resting room (35\%), the personnel finding their own knowledge and practices inadequate $(28.9 \%)$, laboratory coats washed at home $(95 \%)$, educational organization and participation rates $(90 \%)$ and medical waste information levels of the personnel were higher $(p<0.05)$. It was determined that as the age progresses, the rate of education, food and beverage consumption in the laboratory, not being outside the laboratory with protective equipment (gloves, masks and laboratory coats) and the history of laboratory acquired infections were increased $(p<0.05)$. It was observed that washing the laboratory coats at home was higher in the younger age group and hospital washing was higher in the elderly group $(p<0.05)$. There was no significant difference between the genders in terms of food and beverage consumption in the laboratory $(p=0.09)$. It was determined that periodic health checks were not performed in $1 / 3$ of both sexes, but the use of gloves and compliance with medical waste rules was lower in men. Female employees find themselves inefficient in terms of knowledge and practices $(p<$ 0.05). The rate of those who did not have their periodic checkups at regular intervals was higher in the high school and master of science education groups; While non-compliance with medical waste rules, food and beverage consumption in the laboratory was highest in the primary and high school graduates, the lowest rates were found in the master and doctorate groups $(p<0.05)$. The rate of those who had 
regular health checkups was higher in the group of specialist physicians and technicians $(p<0.05)$. It was observed that the rule of not going out of the laboratory with protective equipment was fully observed in the $35+$ years working group, while compliance was $70-85 \%$ in other groups $(p<0.05)$, hepatitis B vaccination rate was highest in specialist doctors and lowest in cleaning and other personnel group $(\mathrm{p}<$ 0.05 ). Highest non-compliance rate with medical waste rules was observed in the cleaning personnel group $(p<0.05)$. As a result, although advances have been made in employee safety practices in medical microbiology laboratories in our country in recent years, it has been found that it is not yet sufficient. The results indirectly reflected the profile of medical laboratories in our country. In the laboratories, physical space and equipment deficiencies should be eliminated, periodic health checkups and vaccination should be provided, non-staff entrance to the laboratory and food, beverage and cigarette consumption should be prevented, laboratory coats should be washed in the hospital, in-service trainings, including medical waste training, should be conducted and these trainings should be developed through mechanisms that will change the behavior.

Keywords: Biosafety; employee; laboratories

\section{Giriş}

Laboratuvar güvenliği uygulamalarındaki amaç; çalışanın kendisini, birlikte çalıştığı kişileri ve çevresini, dökülme, saçılma, elektriksel ve yangın gibi çeşitli kazalara ek olarak oluşabilecek biyolojik, kimyasal ve toksik etkilerden korumaktır ${ }^{1,2}$. Tıbbi laboratuvarların standardizasyonu ile ilgili ölçütler, Uluslararası Standardizasyon Örgütü (ISO)'nün dünya çapında en yaygın genel kalite standartları olan ISO 9000 ve 45000 serisi, "Joint Commission International Accreditation Standards for Hospitals $(\mathrm{JCl})^{\prime \prime}$, Dünya Sağlık Örgütü (DSÖ) standartları ile ülkemizde Sağlık Bakanlığı Sağlıkta Kalite Standartları (SKS) esas alınarak belirlenmektedir ${ }^{3-7}$. Tıbbi laboratuvarların standardizasyonu ile ilgili ölçütler içerisinde yer alan laboratuvar güvenliği konusu çok eski bir konu olup, başta DSÖ olmak üzere çok sayıda ulusal ve uluslararası birçok resmi ve sivil kuruluş, klinik laboratuvarlarda uygulanacak çeşitli güvenlik standartları ile ilgili rehber ve standartları içeren dokümanlar ve kitaplar yayımlamıştır ${ }^{1,8-14}$. Çalışanların sağlığı ve güvenliği ile ilgili uygulamalar resmi otorite, işveren kurum/kuruluşlar ve laboratuvar yöneticilerinin sorumluluğunda$d_{\imath} r^{1,2,15,16}$. Ancak kişinin işi gereği uyması gereken kurallar ve aldığı eğitimler (temel yetki ve sürekli hizmet içi eğitimler) ile birlikte kendi sorumluluğunun da olduğu bilinmeli$\operatorname{dir}^{1,2,15,16}$.

Laboratuvarların güvenliğine ilişkin tehlikeler biyolojik, kimyasal ve fiziksel olarak sınıflandırılmaktadır. Bunların en önemlisi ve yaygın olanı biyolojik tehlikelerdir ${ }^{1,2,8,17-19}$. Araştırma veya klinik laboratuvarlarda çalışmanın enfeksiyon yönünden riskini belirlemeyi amaçlayan geniş kapsamlı ve oldukça detaylı ilk araştırmalar 1949 yılında Sulkin ve Pike'nin yaptığı veri toplama çalışmalarıdır. Bu çalışmalar ilerleyen yıllarda dünya genelindeki birçok laboratuvarı içine alacak şekilde genişletilmiştir. Sulkin ve Pike ${ }^{20,21}$, 19491974 yılları arasında 4000'den fazla laboratuvar enfeksiyonu ve \%4.1 oranında ölüm bildirmişlerdir.

Kesici/delici alet yaralanmaları, laboratuvar kaynaklı enfeksiyon sebepleri arasında ilk sıralarda olup, bulaşta önemli bir yer tutmaktadır ${ }^{19,21,22}$. Bu nedenle kesici ve delici aletlerle yapılan çalışmalarda ve tıbbi atıkların laboratuvardan uzaklaştırılmasında kurallara 
uygun davranılması çok önemlidir. Ayrıca tüm laboratuvar kazalarında kaza formları ve bağışıklama ile ilgili kayıtların tutulmasının yanı sıra kaza geçiren çalışanın izlenmesi de gerekmektedir ${ }^{1,2,9,17,23}$.

Temel laboratuvar güvenliği kavramının ana bileşenleri arasında kişisel koruyucu ekipman ve biyogüvenlik kabinleri (BGK) kullanımı önemli bir yer tutmaktadır. Mikrobiyolojik BGK, ilk olarak 1900'lü yılların başında tüberkülin hazırlanması sırasında Mycobacterium tuberculosis ile oluşabilecek olan laboratuvar kaynaklı enfeksiyonların önlenmesi için bir havalandırmalı kabin oluşturulması şeklinde başlamış ve günümüze kadar çok büyük değişiklikler geçirmiştir ${ }^{1,2,8,9,11,17,23-26}$. Ülkemizde özellikle son on yılda sağlık alanında çalışan güvenliği konusunda önemli gelişmeler yaşanmıştır. Kalite standartları gereği tıbbi laboratuvarlarda güvenlik işlemleri, çalışan/tesis güvenliği çalışmaları, ilgili personel eğitimleri ve sürekli iyileştirmeye yönelik çalışmalar periyodik denetimler ve performans değerlendirme çalışmaları ile yapılmaktadır. Tıbbi laboratuvarlarda olası biyolojik tehlikelerden/enfeksiyon etkenlerinden korunmak amacıyla uygun çalışma ortamının sağlanması, çalışanların laboratuvar biyogüvenlik bilgi düzeyleri ve bu bilgileri uygulamaya ne kadar yansıttıkları önemlidir. Tıbbi laboratuvarlarda meydana gelen kazalarda; insan faktörünün ön plana çıktığı, genellikle teknik hatalar ile çalışanların hatalı tutumlarından veya ihmallerinden kaynaklandığı bildirilmiştir ${ }^{1,2,8,23}$. Literatüre bakıldığında, ülkemizde bu konuda çok az sayıda çalışma olduğu görülmektedir. Ülke genelini yansıtabilecek olan bu çok merkezli çalışmada; tıbbi mikrobiyoloji laboratuvarlarında çalışan güvenliği ile biyogüvenlik uygulamalarının araştırılması ve mevcut durumun ortaya konulması amaçlanmıştır.

\section{GEREÇ ve YÖNTEM}

Bu çalışma, Sakarya Üniversitesi Girişimsel Olmayan Etik Kurulu onayı ile gerçekleştirildi (Tarih: 22.12.2015 ve Karar no: 148).

Bu çok merkezli araştırma 2017 yılında gerçekleştirilmiş olup ülkemizin farklı illerinde faaliyet gösteren 14 üniversitenin tıp fakültesi hastanesi, yedi eğitim ve araştırma hastanesi ve iki devlet hastanesi tıbbi mikrobiyoloji laboratuvarlarında çalışan toplam 1072 personel dahil edildi. Araştırma için tıbbi laboratuvarda çalışan güvenliği ve biyogüvenlik uygulamaları ile ilgili kuralları, görüşleri, tutum ve davranışları tanımlayan bir anket formu hazırlandı. Gönüllülük esasına göre tıbbi laboratuvar çalışanlarına literatürden destek alınarak hazırlanmış 33 sorudan oluşan bir anket yüz yüze görüşülerek uygulandı.

Anketin ilk bölümünde, kurum, yaş, cinsiyet, eğitim düzeyi, meslek grubu, kıdem durumu gibi sosyodemografik özelliklerin saptanmasına yönelik sorulara yer verildi. Çalışma, 14 üniversite tıp fakültesi hastanesi, yedi eğitim ve araştırma hastanesi ve iki devlet hastanesinde yürütüldü. Bu kurumlardaki tıbbi mikrobiyoloji laboratuvarlarında çalışan bütün meslek grupları çalışmaya dahil edildi (Tablo I).

Kurumlar, yaş grupları, cinsiyet, eğitim durumu, çalışma süreleri (kıdem durumu) ve meslek grupları yönünden istatistiksel analizler yapıldı. Araştırmada toplanan veriler SPSS for Windows 16.0 paket programı kullanılarak değerlendirildi (IBM Corp., Armonk, 


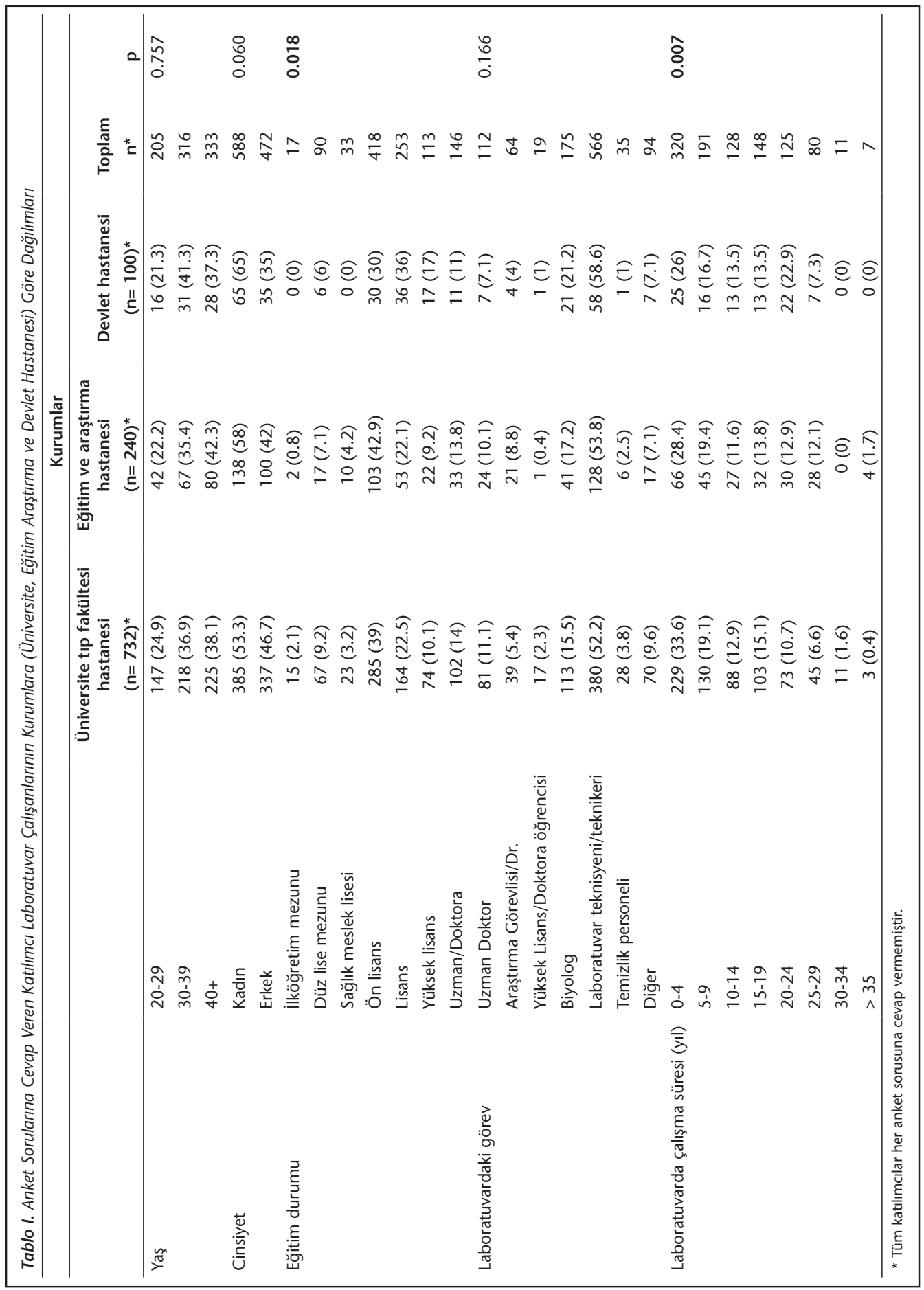


Newyork, ABD). Hipotezlerimizin güvenilirliği için Cronbach Alfa katsayısı hesaplanmıştır. Ayrıca hipotezlerin yorumlanabilmesi için tanımlayıcı istatistikler ve ki-kare testi uygulanmıştır. Sonuçta elde edilen değer, $\mathrm{p}<0.05$ olduğunda istatistiksel olarak anlamlı kabul edildi.

\section{BULGULAR}

Ankete katılan kişilerin yaş, eğitim durumu, medeni durum, hastanedeki görevi ve mesleki tecrübelerine ait veriler Tablo I'de; anket sorularına cevap veren katılımcı laboratuvar çalışanlarının kurumlara (üniversite, eğitim araştırma ve devlet hastanesi) göre dağılımları Tablo I'de, anket soruları ve sorulara verilen cevap dağılımı, yüzdeleri ve istatistiksel analizleri de Tablo II ve III'te sunulmuştur.

\section{Kurumlar Yönünden Yapılan Kıyaslama}

Devlet hastanelerinde yüksek oranda ayrı bir dinlenme odası olmadığı (4. soru; $\mathrm{p}<$ 0.05); en yüksek eğitim düzenlenme ve katılım oranlarının (\%90) devlet hastanelerinde olduğu (5. soru; $p<0.05$ ), devlet hastanesi laboratuvar personelinin kendi bilgi/uygulamalarını daha yetersiz bulduğu (\%28.9) (6. soru; $\mathrm{p}<0.05)$ ancak yüksek oranda tıbbi atık eğitimi aldıkları anlaşılmıştır (8. soru; $\mathrm{p}<0.05)$.

Devlet hastanelerinin laboratuvarlarında yiyecek ve içecek tüketimi (2/3 oranı) ve sigara içme oranı daha yüksek bulunmuştur (12. soru; $\mathrm{p}<0.05$ ). Kişisel koruyucu ekipman temini, koruyucu ekipman kullanımı denetimi, ilk yardım malzemeleri mevcudiyeti ve eldiven çıkarıldıktan sonra her zaman el yıkayan personel oranı devlet hastanelerinde en düşük bulunmuştur (16., 18., 19. sorular; $\mathrm{p}<0.05$ ). Her üç kurumda da laboratuvar kazalarının ancak \%30-40'ının kayıt altına alındığı belirlenmiştir (20. soru; $p<0.05$ ). Devlet hastaneleri laboratuvar personelinin \%20'sinin biyogüvenlik kabininde çalıştığı ve çoğunlukla koruyucu ekipman kullandığı (23. soru; $\mathrm{p}<0.05$ ), \%20'sinin günlük rutin uygulamalarının kendisini korumadığını düşündüğünü (24. soru; $p<0.05$ ), devlet hastanelerinde tüberküloz tanı testlerinin yapılmadığı ya da ayrı/özel bir alan bulunmadığı saptanmıştır (\%74) (25. soru; $\mathrm{p}<0.05$ ). Önlüklerin eve götürülerek yıkanmasının en yüksek oranda devlet hastanelerinde olduğu (\%95) (26. soru; $p<0.05$ ) ve üç kurum tipinde tezgah temizlik oranlarının düşük olduğu belirlenmiştir (günde en az bir defa \%37.255.1; her çalışma sonrasında \%16.3-35.2 oranlarında) (27. soru; $p<0.05$ ).

\section{Yaş Grupları Yönünden Yapılan Kıyaslama}

Eğitim alma, laboratuvarda yiyecek ve içecek tüketimi, koruyucu ekipmanlarla laboratuvar dışına çıkmama, bir şekilde laboratuvarda enfeksiyon bulaşmış olma, rutin koruyucu uygulamaların bulaşıcı enfeksiyonlardan koruduğu düşüncesi $(8,11,17,21$. sorular ile 22 ve 24. sorular) yaş ilerledikçe artmıştır $(p<0.05)$. Laboratuvar kazalarının kayıt/ izleminin yapıldığı yanıtı, 20-29 yaş grubunda düşük bulunmuştur (20. soru; $p<0.05$ ). Önlüklerin 20-29 yaş grubunda evde, ileri yaş grubunda ise hastanede yıkanma oranları daha yüksek bulunmuştur (26. soru; $\mathrm{p}<0.05$ ). 


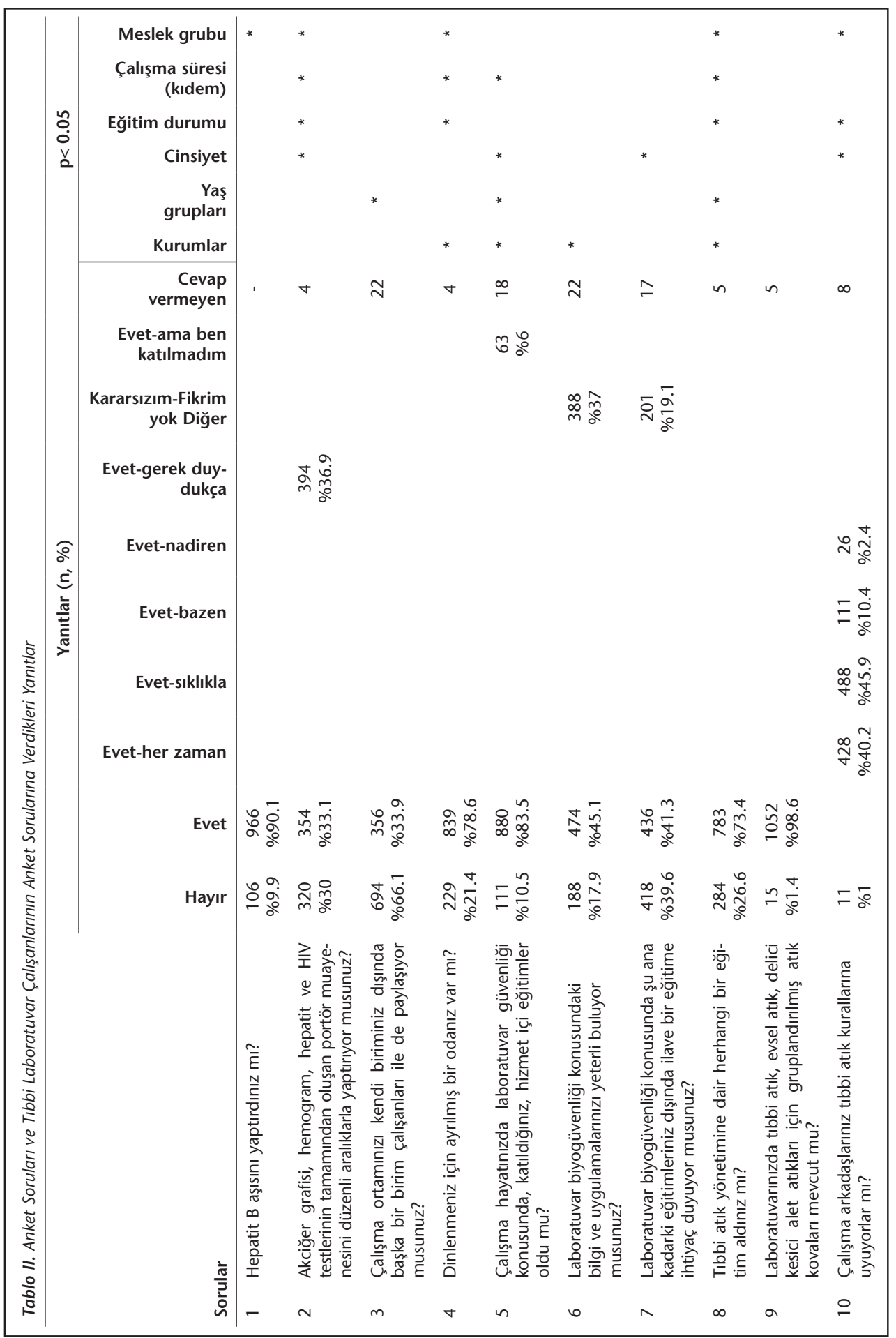




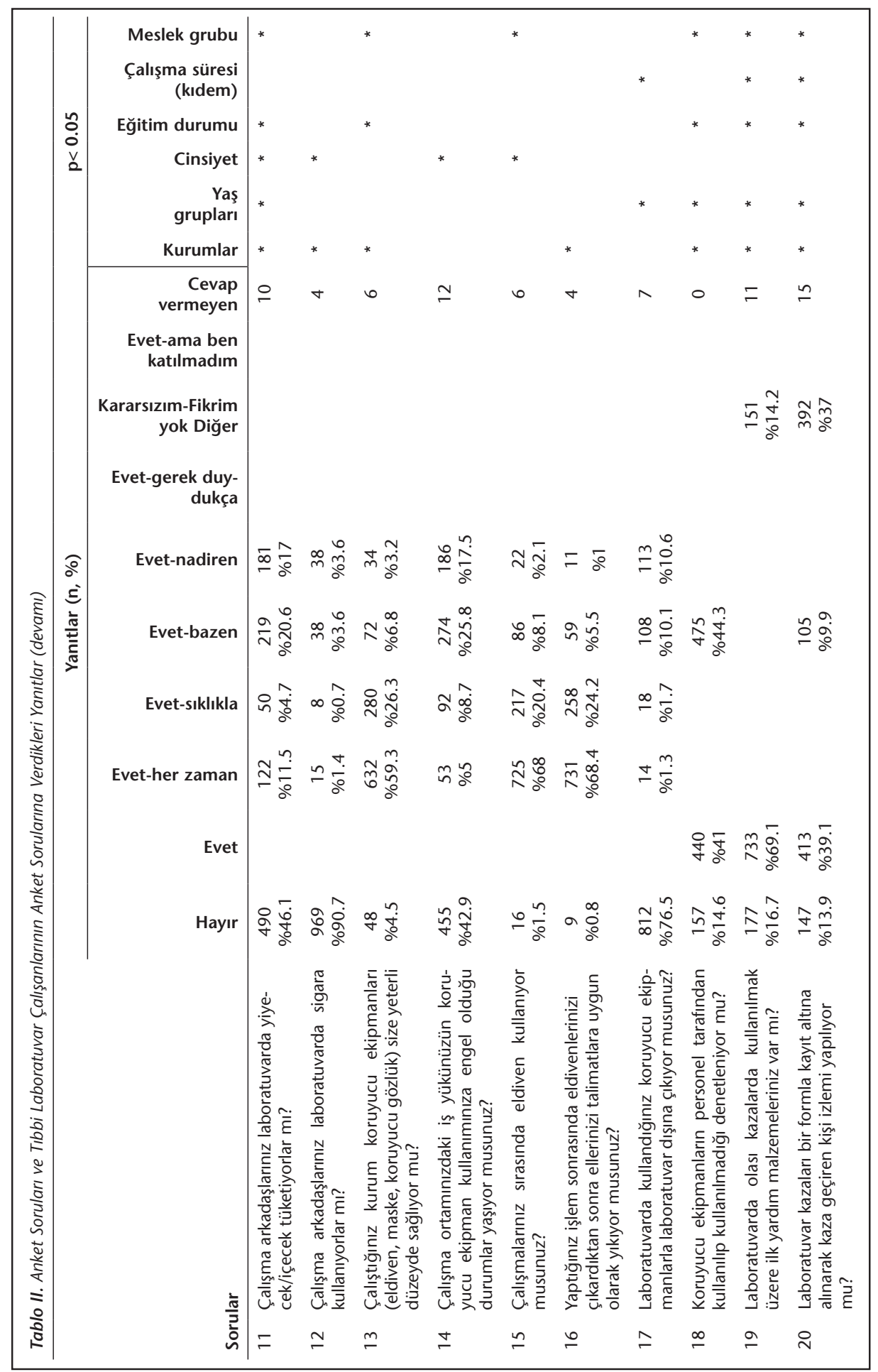




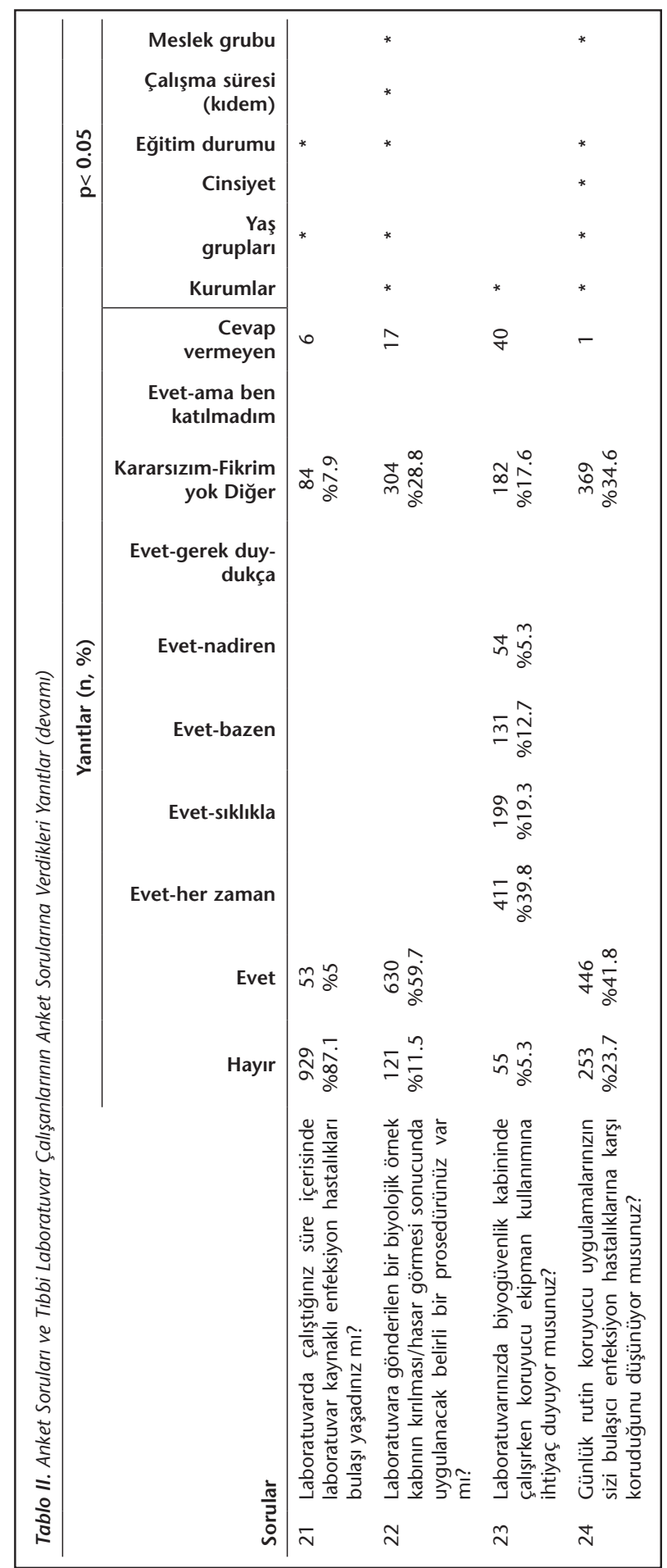




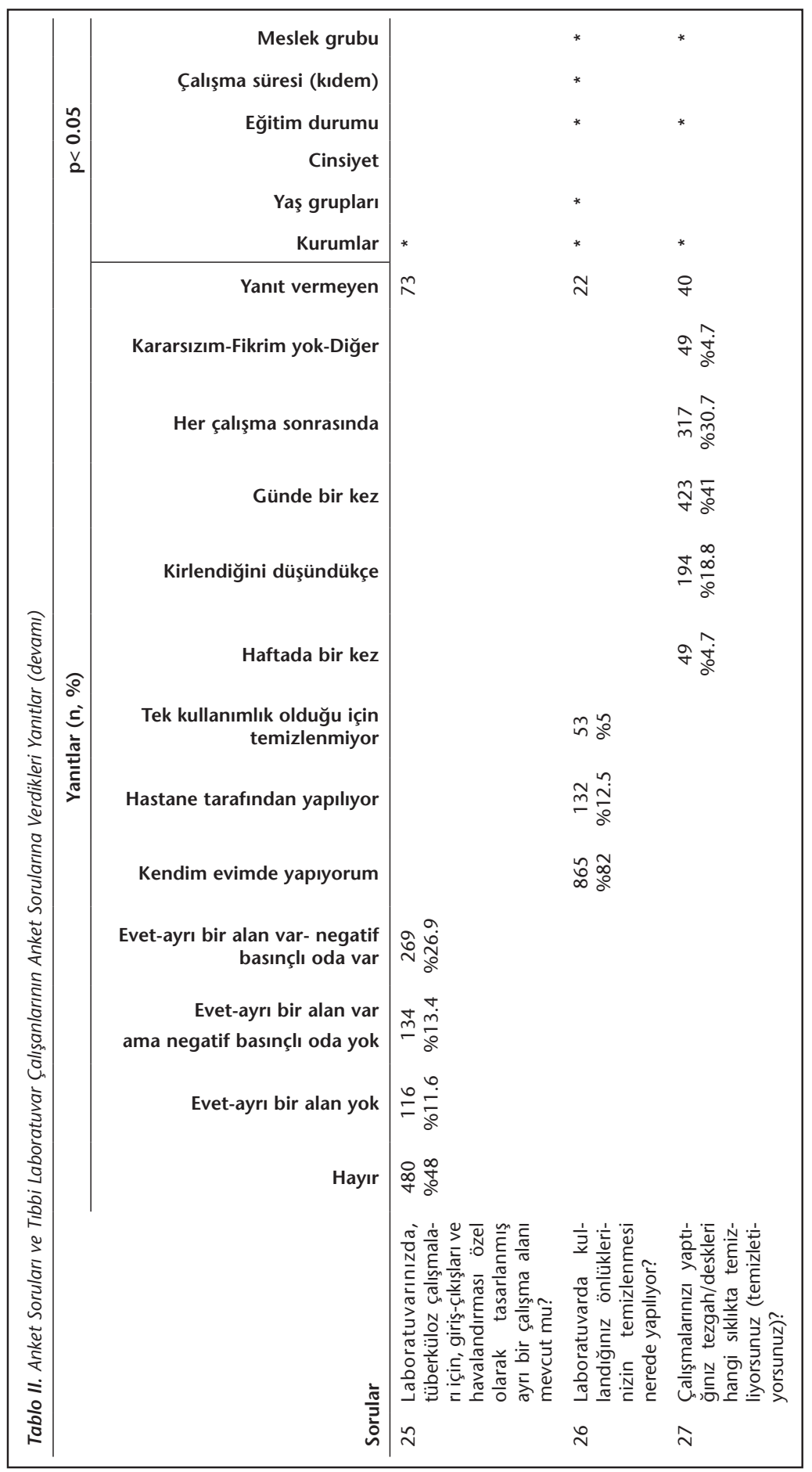




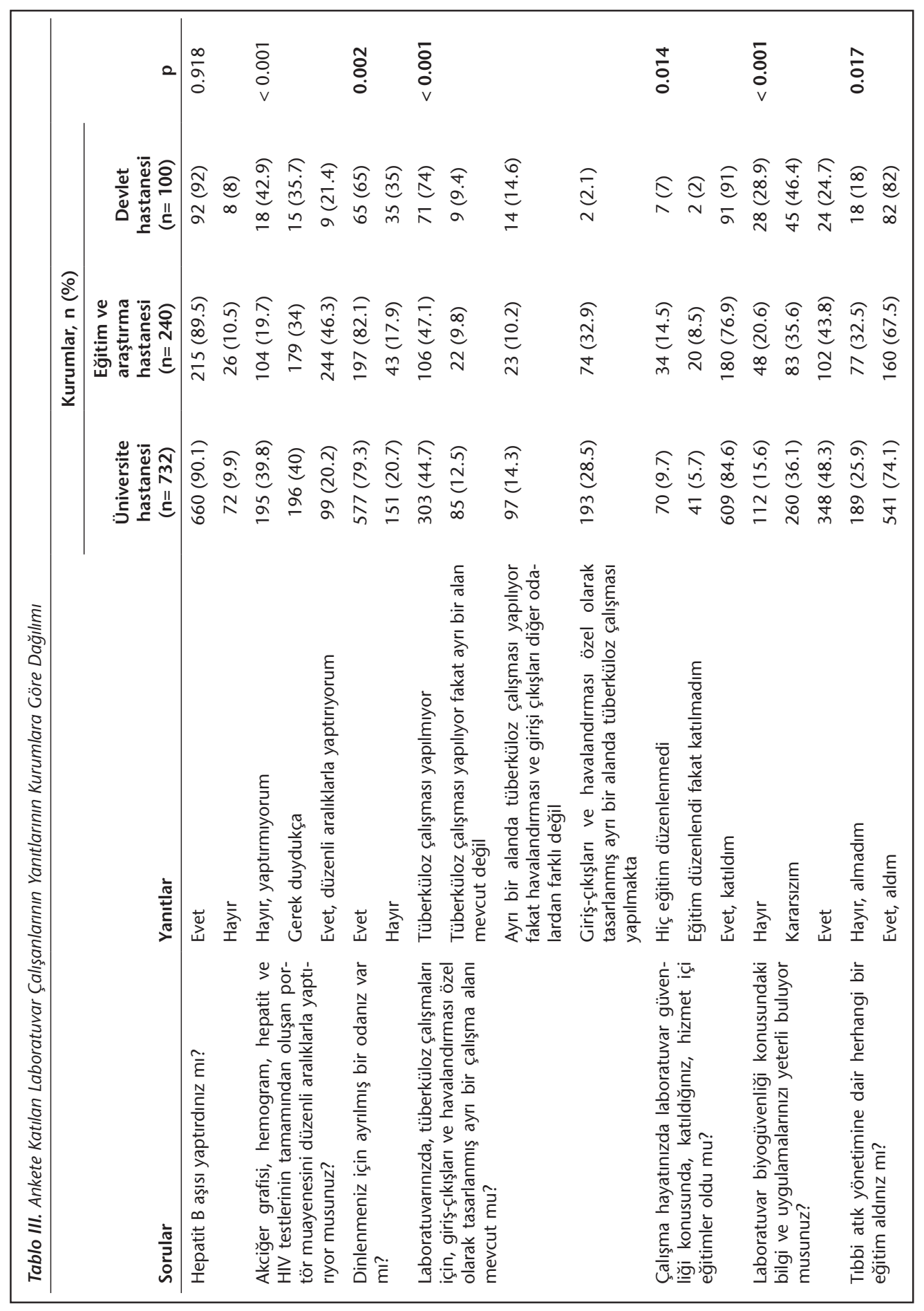




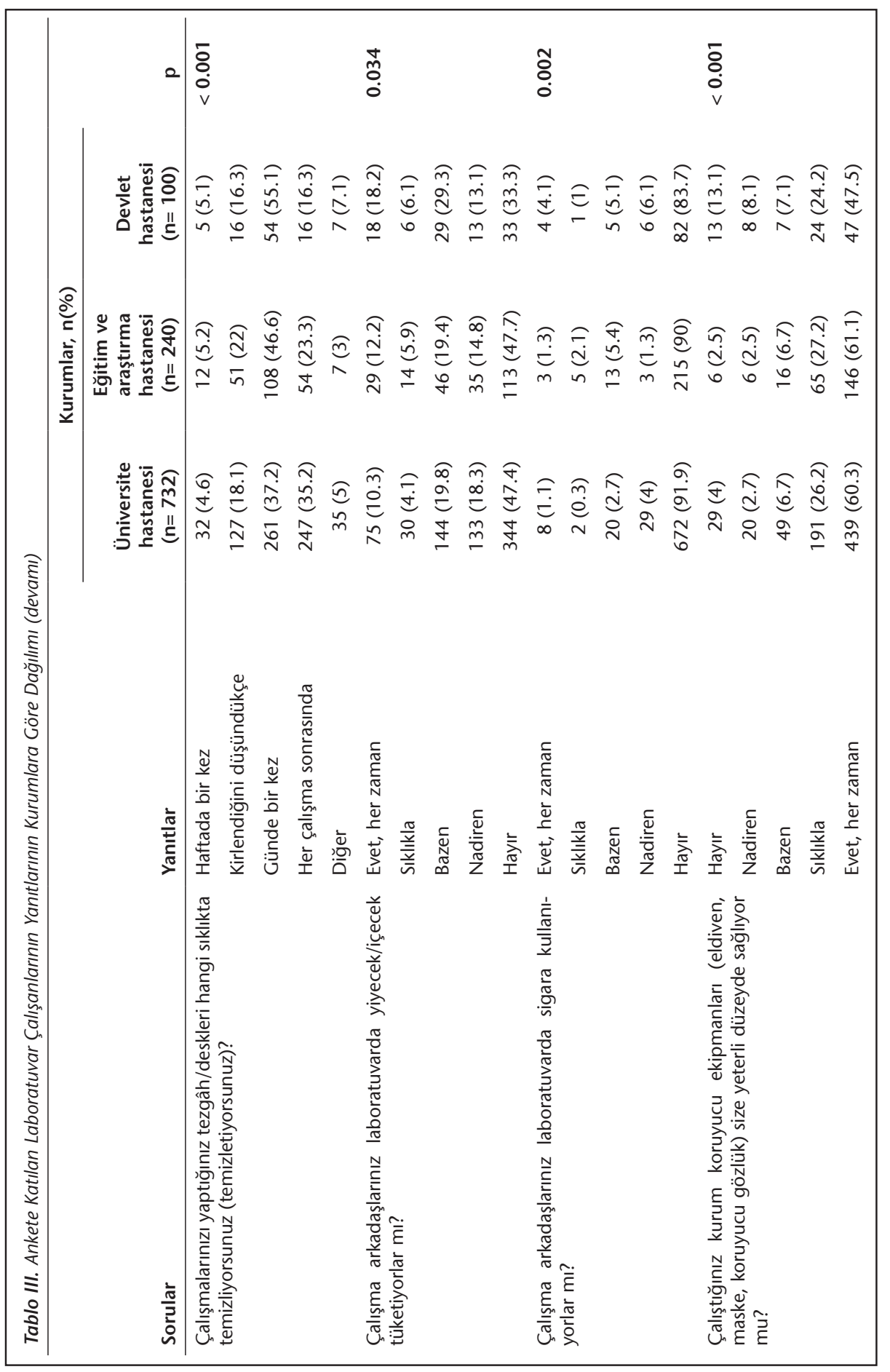




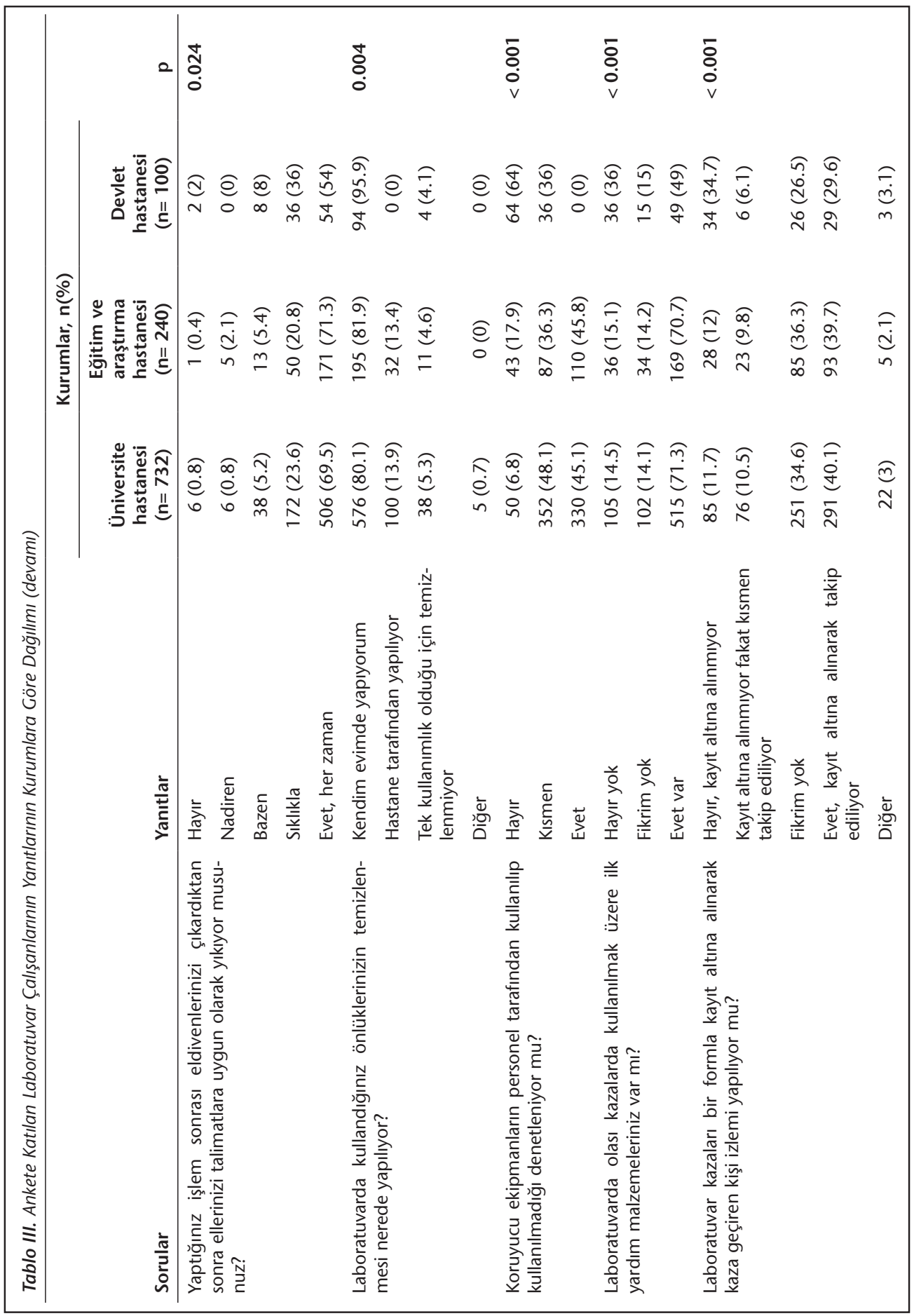




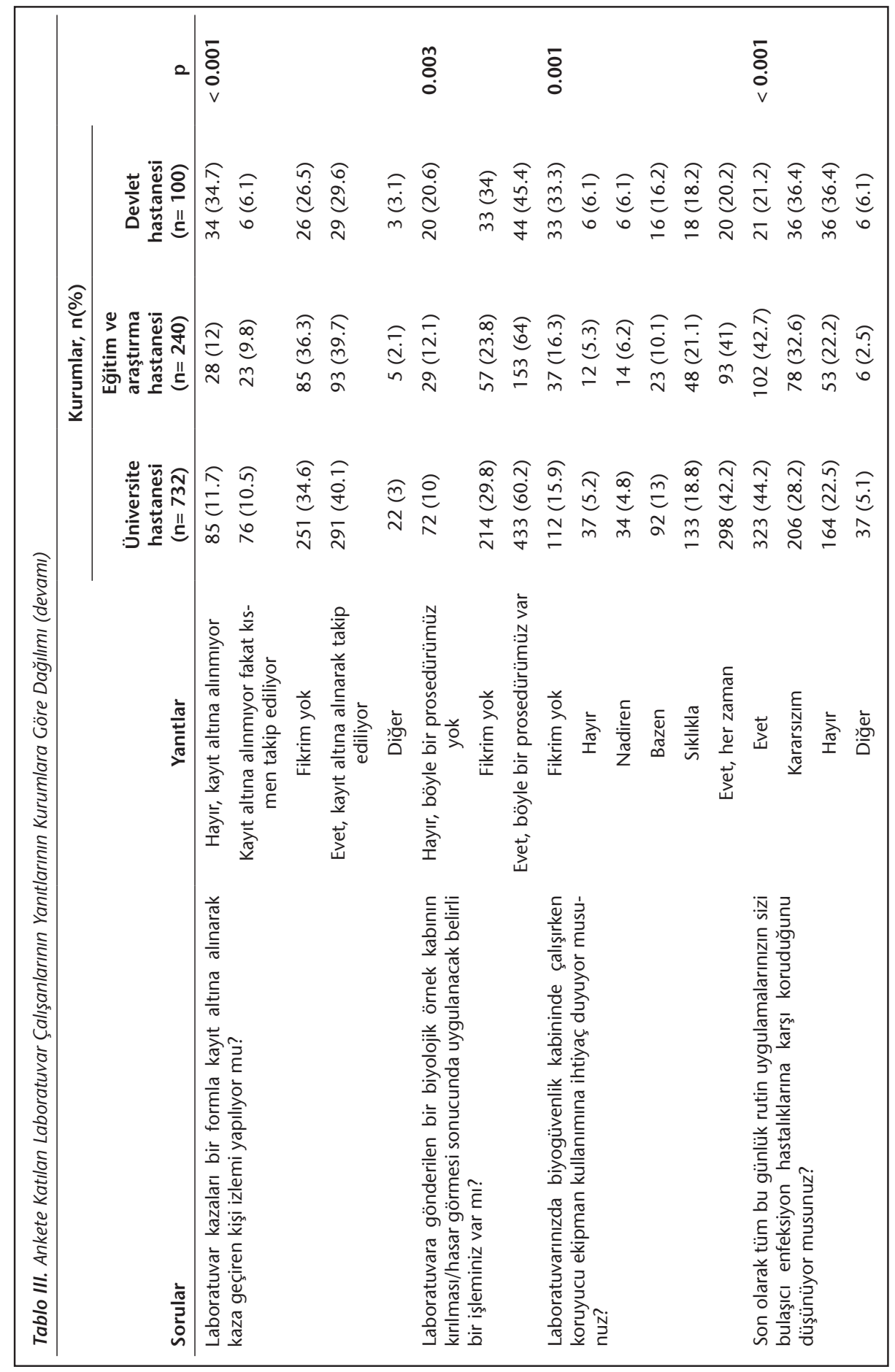




\section{Cinsiyet Yönünden Yapılan Kıyaslama}

Düzenli sağlık kontrollerini yaptırma ancak düzenli eldiven kullanmama ve tıbbi atık kurallarına uymama erkek personelde daha yüksek bulunmuştur $(2,10$ ve 15 . soru; $\mathrm{p}<$ 0.05). Her iki cinsiyette de düzenli sağlık kontrolü yaptırmayan personel oranı $1 / 3$ bulunmuştur.

Laboratuvarda yiyecek ve içecek tüketiminde cinsiyetler arası fark olmadığı görülmüştür (11. soru; $p=0.09$ ). Kadınların, iş yükünün koruyucu ekipman kullanımına engel olmadığını düşündükleri tespit edilmiştir (14. soru; $p<0.05$ ).

\section{Eğitim Durumuna Göre Yapılan Kıyaslama}

Sağlık kontrollerini düzenli yaptırmayanların oranı, lise mezunu ve yüksek lisans grubunda daha yüksek olarak saptanmıştır (2. soru; $\mathrm{p}<0.05$ ). Doktora/uzmanlık eğitimi alan grupta daha düşük oranda tıbbi atık eğitimi alındığı anlaşılmıştır (8. soru; $p<0.05$ ). Tıbbi atık kurallarına uyumsuzluk ilköğretim mezunlarında en yüksek ancak bu kurallara her zaman uyanların oranı doktora/uzmanlık eğitimi düzeyinde en düşük oranda bulunmuştur (10. soru; $p<0.05)$.

Her çalışma sonrası çalışma alanını temizleyenlerin oranı lisans düzeyinde en düşük, bu kurala her zaman uyanların oranı ise genelde yetersiz saptanmıştır (\%30-40) (27. soru; $\mathrm{p}<$ 0.05). Laboratuvarda yiyecek ve içecek tüketimi ilköğretim ve lise mezunları düzeyinde en yüksek, yüksek lisans ve doktora/uzmanlık eğitim düzeyinde en düşük oranda bulunmuştur (11. soru; $p<0.05$ ). İlköğretim mezun düzeyinde, laboratuvar önlüklerini evde yıkama oranı en düşük olarak saptanmıştır (26. soru; $\mathrm{p}<0.05$ ).

Laboratuvar kaynaklı enfeksiyon bulaşı yaşanma öyküsü, en yüksek doktora/uzmanlık eğitimi alan grupta, en düşük ise ilköğretim mezunu grupta belirtilmiştir (21. soru; $p<$ 0.05). Örnek kabının kırılması/hasar görmesi halinde bir uygulama prosedürünün mevcut olduğunu ifade edenler en yüksek oranda doktora/uzmanlık grubu olmuştur (22. soru; $\mathrm{p}<0.05$ ). Rutin koruyucu uygulamaların bulaşıcı enfeksiyonlardan koruduğu düşüncesi, ilköğretim mezunu ve doktora/uzmanlık grubunda en yüksek bulunmuştur (\%57-58) (24. soru; $p<0.05$ ).

\section{Çalışma Süresine (Kıdem) Göre Yapılan Kıyaslama}

Sağlık kontrollerini düzenli aralıklarla yaptıranların oranı, çalışma süresi fazla olan grupta en yüksek orandadır (20-24. ve 25-29. yıl) (2. soru; $p<0.05$ ). Hizmet içi eğitimler 0-4 yıl deneyimli grupta, hiç eğitim düzenlenmedi şeklindeki "hayır" yanıtı en yüksek bulunmuştur (\%17.6) (5. soru; $p<0.05)$. Eğitimlere katılma oranı kıdem arttıkça artmakta ve > 35 yıl çalışan grupta \%100'e ulaşmaktadır. Tıbbi atık eğitimi almadığını ifade edenler; 0-4, 5-9 ve > 35 yıl (\%33-35) çalışan gruplarında yüksek bulunmuştur (8. soru; $p<0.05$ ). Aksine eğitim aldığını ifade edenlerin oranı, 30-34 yıl grubunda \%100'e ulaşmaktadır.

Koruyucu ekipmanla laboratuvar dışına çıkmama kuralına > 35 yıl çalışan grupta tam uyum varken, diğer gruplarda uyum \%70-85 oranında kalmıştır (17. soru; $p<0.05$ ). Ka- 
zaların kayıt ve takibinin yapıldığı konusunda, 10-14 yıllık kıdemi olan çalışan grubunda en yüksek "hayır" ve > 35 yıl çalışan grubunda en yüksek "evet" yanıtı alınmıştır (20. soru; $\mathrm{p}<0.05$ ).

\section{Meslek Grubuna Göre Yapılan Kıyaslama}

Hepatit B aşısı yaptırma oranı en yüksek uzman hekim grubunda, en düşük ise temizlik ve diğer personel grubunda izlenmiştir (1. soru; $p<0.05$ ). Sağlık kontrollerini düzenli yaptıranların oranı uzman hekim ve laboratuvar teknisyeni grubunda yüksek, yüksek lisans/doktora öğrencisi grubunda düşük bulunmuştur (2. soru; $\mathrm{p}<0.05$ ).

Ayrı bir odası olma durumu uzman hekim grubunda yüksek düzeyde (\%91) mevcutken, temizlik personelinde oran $\% 50$ 'dir (4. soru; $p<0.05$ ). Yüksek lisans/doktora öğrencilerinin yaklaşık \%60'ı tıbbi atık eğitimi almadığı (8. soru; $p<0.05$ ), laboratuvar teknisyeni olan grupta ise yüksek oranda eğitim aldıkları saptanmıştır. Tıbbi atık kurallarına uymayanların oranı temizlik personelinde yüksek iken kurallara uyanlarda oran araştırma görevlisi/Dr. grubunda en düşük bulunmuştur (\%23) (10. soru; $p<0.05)$.

Laboratuvarda yiyecek/içecek tüketimi, yüksek lisans/doktora öğrencisi grubunda en düşük oranda gözlenmiştir (11. soru; $p<0.05$ ). Her zaman koruyucu ekipman sağlandığını ifade edenler, laboratuvar teknisyenleri ve temizlik personelidir (13. soru; $\mathrm{p}<$ 0.05). Düzenli eldiven kullananların oranı yüksek lisans/doktora öğrencileri grubunda yüksek bulunmuştur (15. soru; $p<0.05$ ). Laboratuvarda ilk yardım malzemeleri varlığı konusunda uzman hekim grubu en yüksek "evet" yanıtı vermiş̧tir (19. soru; $p<0.05$ ). "Laboratuvar kazaları kayıt altına alınarak takip ediliyor" ifadesi ile hasta örnek kabının kırılması/hasar görmesi halinde uygulama prosedürünün mevcut olduğunu belirten grup en yüksek oranda uzman hekimler olmuştur (\%82) (20. ve 22. soru; $\mathrm{p}<0.05$ ). Kabinde çalışırken her zaman koruyucu ekipman kullananlar en yüksek oran ile uzman hekim ve yüksek lisans/doktora öğrencisi grupları olmuştur (\%52) (23.soru; $p<0.05$ ). Önlüklerinin hastanede yıkandığını ifade edenler içerisinde en yüksek oran uzman hekim grubu olmakla birlikte, sağlık personelinin \%80'inden fazlası önlüklerini hastanede yıkatmamaktadır (26. soru; $p<0.05$ ). Her çalışma sonrası çalışma alanını temizleyenlerin oranı yüksek lisans/doktora öğrencisi grubunda en yüksek (\%63), bu kurala her zaman uyanların oranının ise yetersiz düzeyde olduğu saptanmıştır (\%27-46) (27. soru; $p<0.05)$.

\section{TARTIŞMA}

Hastaneler ve özellikle tıbbi laboratuvarlar çok tehlikeli iş yeri sınıfında yer almaktadır$\operatorname{lar}^{1,17,18}$. Çünkü tıbbi laboratuvarlarda; kimyasal, yangın, elektrik ve radyoaktif tehlikeler gibi güvenlik risklerine ek olarak, özellikle mikrobiyoloji laboratuvarında enfeksiyöz ajanlar ya da biyolojik tehlikelere maruz kalma riski de ön plana çıkmaktadır ${ }^{1,2,8,11,17,19,22-26}$. Tıbbi laboratuvarlarda incelenen klinik örnekler; çalışanlar için potansiyel tehlike oluşturan insan immün yetmezlik virüsü (HIV), hepatit B virüsü (HBV), hepatit C virüsü ve diğer birçok bakteri (Brucella, tüberküloz, tularemi vb.), virüs ve mantar içerebilir ${ }^{1,2,8,11,17,19,22-26}$. 
Mikrobiyoloji laboratuvarında oluşabilecek enfeksiyonlar; kazalar (kesici-delici alet vb.) sonucunda soluma, yutma, direkt inokülasyon, mukozal temas ve eklem bacaklı vektörler ile bulaşabilmektedir. Tıbbi laboratuvar birimlerinde çalışanların, potansiyel tehlikeleri, acil (kaza anı, kaza sonrası süreçler vb.) ve normal durumlarda ne yapacaklarını bilmeleri gerekir $^{1,2,8,11,17,19,22-26}$. Ancak, bu çalışmada ve bazı çalışmalarda da vurgulandığı gibi personelin güvenli çalışma tedbirleri konularında arzu edilen düzeyde olmadıkları görülmektedir $^{17,22-24}$. Bu çalışmada, sağlık kontrollerini düzenli aralıklarla yaptıranların yaklaşık $1 / 3$ oranında olduğu görülmüştür. Bu konunun hem yasal hem de bilimsel yönden ihmal edilmemesi gerekir. Tüm personelin HBV gibi rutin aşıların ve periyodik kontrollerinin yapılması/yaptırılması sağlanmalıdır. Ülkemizde bu konuda olumlu uygulamalar/gelişmeler yaşanmakta olup, bu tip kontrollerini yaptırmayan işverene ve personele ceza uygulanacağı belirtilmektedir ${ }^{28}$.

Koruyucu ekipman/giysi kullanımı konusunda farkındalığın, bilinçlenmenin ve kullanımının, laboratuvar kaynaklı kazaların yol açtıkları zararların azaltılmasında oldukça etkili olduğu bilinmektedir 1,2,8,9-11,17,23,24. Tıp fakültesi öğrencileri üzerinde yurt dışında yapılan bir araştırmada \%95'inin önlük kullandığı, İspanya'da laboratuvar çalışanlarının yarısından fazlasının maske kullandığı belirlenmiştir ${ }^{25,29}$. Ülkemizde bu konuda yapılan bir araştırmada, katılımcıların \%1.9'unun sürekli olarak, \%46.1'inin ise ara sıra koruyucu maske kullandığı, koruyucu gözlük kullananların oranının da \%1.9 olduğu bildirilmiştir ${ }^{24}$. Kişisel koruyucu malzemeleri çalışmalar sırasında kullanma alışkanlığı, sadece laboratuvar çalışanlarının biyogüvenlik konusunda eğitimli olup olmadıklarına bağlanamaz. Bu durum, çalışanların iş yükü ve sosyokültürel alışkanlıklarının yanı sıra kurumun biyogüvenlik politikası ve ekonomik olanakları ile de yakından ilişkili olabilmektedir².

Laboratuvar çalışmaları sırasında eldiven kullanımı çok önemlidir. Eldiven, laboratuvarda güvenli çalışma için gerekli koruyucu malzemelerin başında gelmektedir. Ülkemizde, sağlık çalışanları arasında sürekli eldiven kullanımı oranının \%28.8, ara sıra eldiven kullanımı oranı ve sürekli kullanım oranının ise toplam $\% 85.7$ olduğu bildirilmiştir ${ }^{24}$. Çalışmamızda, laboratuvarda sürekli ve sıklıkla eldiven kullanımı oranının yüksek ( \%90) olduğu görülmüştür. Kişisel koruyucu ekipman temini ve kullanımı konusunda olumsuzluk/yetersizlik yaşanmaması gerekmektedir. Koruyucu ekipman ile laboratuvar dışına çıkış sıfırlanmalıdır. Biyogüvenlik kabininde çalışırken tüm personelin koruyucu ekipman kullanımı sağlanmalıdır. Koruyucu ekipmanların personel tarafından kullanılıp kullanılmadığı denetlenmelidir (Tablo I). Koruyucu ekipman kullanımı ile ilgili sorunlar, periyodik farkındalık eğitimleri ile bunun her çalışanın kendi sorumluluğunda olduğu kavrandığında çözülebilir ve ihmallerin önüne geçilebilir.

Bu çalışmada; yaş ve çalışma süresi ilerledikçe doğal olarak eğitim alma, eğitime katılma oranları artmakta olup, periyodik sağlık kontrollerini yaptırma oranı, koruyucu ekipmanlarla laboratuvar dışına çıkmama ve çalışma ortamını başka birim çalışanları ile paylaşmama kuralına uyulduğu görülmüştür. Ancak, ileri yaş grubunda laboratuvarda yiyecek ve içecek tüketiminin arttığı saptanmıştır. Deneyim artışı insanlarda öz güven/hata 
yapmam/bana bir şey olmaz duygusu oluşturmakta ve iş konusunda bazı inmalleri beraberinde getirmektedir ${ }^{24,30}$. Çalışmamızda, genç yaş grubunda önlükleri evde yıkama işleminin, ileri yaş grubunda da hastanede yıkamanın yüksek oranda olduğu görülmüştür.

Laboratuvar çalısanlarının biyogüvenlik konusunda yeterli bilince sahip olmamaları, kendi güvenlikleri için önemli bir sorun oluşturmaktadır. Deneyimsizlik ve yeterli eğitim alınmamış olması da laboratuvar kaynaklı enfeksiyonlarda çok önemli bir yer oluşturmaktadır. İzmir'de üç büyük hastanenin laboratuvar çalışanlarının biyogüvenlik ile ilgili eğitim alma oranının \%10.3-33 olduğu bildirilmiştir ${ }^{23}$. Bu nedenle tıbbi laboratuvarlarda sürekli hizmet içi farkındalık eğitimleri, periyodik takip ve denetimler yapılmalıdır ${ }^{1,17}$. Düşük eğitim oranları ve davranış değişikliğine yansımayan eğitimlerin çalışanların laboratuvarda bazı yanlış alışkanlıkların sürdürülmesine neden olduğu ve laboratuvar içi kazalarla birlikte enfeksiyon bulaş riskini artırabileceği de ifade edilmiş̧ir ${ }^{2}$. Ancak, tespit edilen laboratuvar kazalarının \%30'unun daha önce laboratuvar güvenliği eğitimi almış personelde görüldüğü de bilinmektedir ${ }^{1}$.

Bu çalışmada, hizmet içi eğitimlerin yüksek oranda yapıldığı saptanmıştır. Ancak, eğitimlere yeni başlayan personel ve tüm meslek gruplarının katılımı sağlanmalıdır. Sağlık Bakanlığı ile hastane ve laboratuvar yönetimleri, laboratuvar personeli için sürekli eğitim ve bilgilendirme politikası oluşturmalı ve uygulamalıdırlar. Eğitimlerle yetinilmemeli bu eğitimlerin davranış değişikliği ve personelin performansına yansıma düzeyleri de sürekli ölçülmelidir ${ }^{1}$. Ancak, her zaman ve her kurumda bunu sağlamak mümkün olamayabilir. Bu konuda ülkemizde yapılan sınırlı sayıda çalışma vardır. Bu çalışmaların birisinde; laboratuvarların \%58.2'sinde biyogüvenlik bilincinin oluşturulması, hizmet içi eğitimin sürdürülmesi ve sürecin denetlenmesi için her hangi bir uzman bulunmadığı rapor edilmiştir $^{31}$. Söz konusu bu çalışma yaklaşık 13 yıl önce yapılmıştır. Son yıllarda uygulanan kalite standartları ve gelişen mevzuatla beraber bir kısım eksiklikler olsa da, biyogüvenlik bilincinin, uygulamalarının ve yetkin uzman sayılarının eskiye göre çok daha iyi olduğu gözlenmektedir. Çalışmamızdaki sonuçlara göre; tıbbi atık ve diğer atık kutularının yaklaşık \%98-99 oranında sağlanıyor olması olumlu bir durumdur. Ancak, tıbbi atık kurallarına tüm personelin uyumu sağlanmalıdır (Tablo I).

Laboratuvar davranışları ve iş alışkanlıklarının laboratuvarda meydana gelebilecek kazalar açısından önemli olduğu ve kazaların devamına neden olduğu belirtilmektedir ${ }^{1}$. Bunlara ek olarak tıbbi laboratuvarlarda meydana gelen kazaların genellikle teknik hatalar ve çalışanların hatalı tutumlarından veya inmallerden kaynaklandığı bildirilmiş olup, insan faktörünün ön plana çıktığı vurgulanmaktadıı ${ }^{1,2,8,23}$. Çalışan hatası sonucu oluşan kazaların en önemli kaynağı olarak; bilgisizlik, önemsememe, dikkatsizlik, aşııı güven ve psikolojik faktörler gösterilmektedir². Ayrıca gereğinden hızlı çalışıldığı zamanlarda ya da tam öğlen yemeği ve gün sonunda dalgınlığın arttığı zamanlarda kazaların daha sık ortaya çıktığı gözlemlenmiştir ${ }^{1}$. Laboratuvarların tümünde ilk yardım malzemesi bulunmalıdır. Bu çalışmada; laboratuvar kazalarının yaklaşık \%40 oranında kayıt altına alınıyor olması dikkat çekici bulunmuştur. Laboratuvar kaynakıı enfeksiyon bulaşı mutlaka kayıt 
altına alınmalı ve izlenmelidir. Tüm dünyada ve ülkemizde bu konuda yetersizlikler var$\operatorname{dir}^{12,17,24}$.

Her türlü kontaminasyona açık olan laboratuvar ortamlarında, personelin yiyecek ve içecek tüketmesi, kendilerini enfekte etmeleri açısından son derece tehlikelidir. Dünya genelinde laboratuvarda yiyecek ve içecek tüketimi oranı, \%1.4-12 olarak bildirilmiştir ${ }^{29,32}$. Ülkemizde bu oran, \%38.3 olarak bildirilmiştir ${ }^{23}$. Çalışmamızda, laboratuvarda sigara ve yiyecek/içecek tüketiminin yaklaşık \%50 oranında olduğu saptanmıştır. Çok yüksek olan bu oran büyük bir risk oluşturmaktadır. Laboratuvarda sigara ve yiyecek/içecek tüketiminin ivedilikle önüne geçilmelidir.

Çalışmamızdaki önemli bulgulardan birisi de laboratuvarda kullanılan önlüklerin hastanede özel olarak yıkanmamasıdır ( \%80, Tablo I). Bu sorun ülkemizdeki birçok hastanede önemli bir eksikliktir ve önlüklerin evsel çamaşırlarla birlikte evde yıkanmaları biyolojik tehlikelere kapı açmaktadır.

Araştırma sonuçlarımız ve gözlemsel tespitlerimize göre, önemli sorunlardan birisi de laboratuvar çalışma alanlarına yetkisiz kişilerin çok fazla oranda girip çıkması ve bu alanlarda bulunmasıdır. Laboratuvara başka insanların girişi olduğu ve ortamın başka bir birim çalışanları ile de paylaşılıyor olması durumu ( 1/3) üzerinde önemle durulması gereken bir konudur. Kartlı geçiş vb. tedbirler ile bu sorunun önüne geçilebilir. Kişisel koruyucu ekipmanla laboratuvar dışına çıkılmasının önlenmesi de gerekmektedir. Ayrıca birçok laboratuvarda personele ait ayrı bir dinlenme odasının bulunmadığı tespit edilmiştir ( \%20).

M.tuberculosis, Francisella tularensis, Brucella spp., Ebolavirüs, Kırım-Kongo kanamalı ateşi virüsü gibi riskli mikroorganizmalar ile çalışılması durumunda, yüksek biyogüvenlik düzeyine sahip ortamlara gereksinim vardır. Araştırma kapsamımızda yer alan hastanelerin \%48'inde ayrı bir tüberküloz laboratuvarı bulunmadığı saptanmıştır. Sadece $1 / 4^{\prime}$ ünde biyogüvenlik düzeyi 3 olan oda mevcuttur ve bu konuda iyileştirmeler yapılmalıdır.

Tıbbi laboratuvarlarda kimyasal madde yönetimi ve tesis kaynaklı olarak tarif edilen; yangın, patlama, su baskını, deprem, elektrik riskleri vb. tehlikelere karşı önlem alınmaIıdır. Ülkemizde çalışan güvenliği alanındaki çalışmalar henüz yeterli düzeyde değildir. Tüm tıbbi laboratuvarlarda detaylı risk analizleri yapılarak eksiklikler giderilmelidir 1,2,23,24.

Sonuçta, ülkemizde tıbbi mikrobiyoloji laboratuvarlarında çalışan güvenliği uygulamalarında olumlu gelişmelere rağmen ideal noktada olunmadığı kesindir. Çalışmada elde edilen veriler, ülkemiz tıbbi laboratuvarlarının genel bir profilini yansıtmaktadır. Laboratuvar güvenliğinin sağlanması, fiziki mekan ve ekipman eksikliklerinin giderilmesi, personelin periyodik sağlık kontrolleri ve aşılanmalarının sağlanması, laboratuvara personel harici kişilerin girişinin engellenmesi, laboratuvarda yiyecek/içecek tüketilmemesi ve sigara içilmemesi, önlüklerin hastanede yıkanması, tıbbi atık eğitimi dahil hizmet içi eğitimlerin yapılması ve bu eğitimlerin davranış değişikliği sağlayacak şekilde geliştirilmesi öncelikli alanlar olarak ele alınmalıdır. 


\section{ETIK KURUL ONAYI}

Bu çalışma, Sakarya Üniversitesi Girişimsel Olmayan Etik Kurulu onayı ile gerçekleştirildi (Tarih: 22.12.2015 ve Karar no: 148).

\section{ÇIKAR ÇATIŞMASI}

Yazarlar bu makale ile ilgili herhangi bir çıkar çatışması bildirmemişlerdir.

\section{KAYNAKLAR}

1. Başustaoğlu A, Güney M. Klinik Mikrobiyoloji Laboratuvarlarında Biyogüvenlik. Klinik Mikrobiyoloji uzmanlık Derneği Yayınları No: 2. Sim Matbaacılık 2012, Ankara. https://www.klimud.org/public/uploads/ dosya/1354802844.pdf. Erişim Tarihi 10.10.2019

2. Karaman M. Temel laboratuvar güvenliği ve ülkemizdeki duruma genel bakış. J Clin Analytical Med 2011; 2(3): 130-4.

3. ISO 9001:2015 Quality management systems-Requirements. https://www.iso.org/standard/62085.html. Erişim Tarihi: 10.10.2019.

4. Joint Commission International Accreditation Standards for Laboratories. 3rd Edition,2017.https://www. jointcommissioninternational.org/assets/3/7/JCl_Standards_for_Laboratories_Standarts-Only.pdf. Erişim Tarihi: 10.10.2019.

5. ISO 45001:2018 Occupational health and safety management systems-Requirements with guidance for use. https://www.iso.org/standard/63787.html. Erişim Tarihi: 10.10.2019.

6. Laboratory Quality Standards and their Implementation. World Health Organization 2011. http://apps. who.int/medicinedocs/documents/s22409en/s22409en.pdf?ua=1. Erişim Tarihi: 10.10.2019.

7. Sağlıkta Kalite Standartları Hastane. T.C. Sağlık Bakanlığı, Sağlık Hizmetleri Genel Müdürlüğü Sağlıkta Kalite ve Akreditasyon Daire Başkanlığı SKS-Hastane (Versiyon-5; Revizyon-01), 1. Revizyon-2. Baskı: Ankara, Mart 2016.

8. Laboratory biosafety manual. Third edition. World Health Organization, Geneva, 2004, http://www.who. int/csr/resources/publications/biosafety/Biosafety7.pdf. Erişim Tarihi: 10.10.2019.

9. Klinik Mikrobiyoloji Laboratuvarları Kalite Yönetimi Rehberi. T. C. Sağlık Bakanlığı Sağlık Hizmetleri Genel Müdürlüğü, Sağlıkta Kalite ve Akreditasyon Daire Başkanlığı. Pozitif Matbaa, 1. Basım, Ankara, Ocak 2014. https://dosyahastane.saglik.gov.tr/Eklenti/52175,25-klinik-mikrobiyoloji-laboratuvari-kalite-yonetimirehberi-02012014pdf.pdf?0. Erişim Tarihi: 10.10.2019.

10. Laboratory Safety Guidance Occupational Safety and Health Administration. U.S. Department of Labor. https://www.osha.gov/Publications/laboratory/OSHA3404laboratory-safety-guidance.pdf. Erişim Tarihi: 10.10.2019.

11. Biosafety in Microbiological and Biomedical Laboratories. U.S. Department of Health and Human Services Public Health Service Centers for Disease Control and Prevention National Institutes of Health 5th Edition, HHS Publication No. (CDC) 21-1112, Revised December 2009. https://www.cdc.gov/labs/pdf/CDC-Biosaf etyMicrobiologicalBiomedicalLaboratories-2009-P.PDF. Erişim Tarihi: 10.10.2019.

12. Principles of Laboratory Biosafety. Centre for Biosecurity of the Public Health Agency of Canada and the Office of Biohazard Containment and Safety of the Canadian Food Inspection Agency. https://trainingformation.phac-aspc.gc.ca/course/index.php?categoryid=2\&lang=en. Erişim Tarihi: 10.10.2019.

13. Abacıoğlu YH, Sönmez C (Editörler) Ulusal Mikrobiyoloji Standartları, Laboratuvar Güvenliği Rehberi. T.C. Sağlık Bakanlığı, Türkiye Halk Sağlığı Kurumu Başkanlığı, Mikrobiyoloji Referans Laboratuvarları Daire Başkanlığı, Ankara- 2014.

14. Dunne M Jr, Larocco MT. Laboratuvar yönetimi, Çeviri: Başustaoğlu A, Klinik Mikrobiyoloji (Manual of Clinical Microbiology, 9. Baskı Çevirisi), 2009. 
15. 6331 Sayılı İş Sağlığı ve Güvenliği Kanunu (R.G. 30.06.2012/28339).

16. İş Sağlığı ve Güvenliği Yönetmeliği (R.G. 09.12.2003/25311).

17. Murat $E$, Köroğlu M, Altındiş M. Bir olgu sunumu üzerinden laboratuvar güvenliği ve kalite standartları. Türk Klinik Laboratuvar Dergisi 2014; 5(1): 9-13.

18. İş Sağlığı ve Güvenliğine İlişkin İşyeri Tehlike Sınıfları Tebliğinde Değişiklik Yapılmasına Dair Tebliğ. https:// www.resmigazete.gov.tr/eskiler/2017/02/20170227M1-1.htm. Erişim Tarihi: 10.10.2019.

19. International Hazard Datasheets on Occupation. Laboratory Worker. https://www.ilo.org/wcmsp5/groups/ public/---ed_protect/---protrav/---safework/documents/publication/wcms_193093.pdf. Erişim Tarihi: 10.10.2019.

20. Sulkin SE, Pike RM. Viral infections contracted in the laboratory. N Engl J Med 1949; 241(5): 205-13.

21. Pike RM. Laboratory-associated infections: incidence, fatalities, causes, and prevention. Annu Rev Microbiol 1979; 33: 41-66.

22. Özen M, Özen NM, Kayabaş Ü, Köroğlu M, Topaloğlu B. Biyokimya laboratuvarı personelinin iş kazaları hakkındaki bilgi ve tutumları. İnönü Üniversitesi Tıp Fakültesi Dergisi 2006; 13(2): 87-90.

23. Aksoy Ü, Özdemir MH, Usluca S, Ergönen AT. İzmir'deki üç eğitim hastanesinde laboratuvar çalışanlarının biyogüvenlik profili. Mikrobiyol Bul 2008; 42(3): 469-76.

24. Ergonul O, Celikbas A, Tezeren D, Guvener E, Dokuzoguz B. Analysis of risk factors for laboratory-acquired Brucella infections. J Hosp Infect 2004; 56(3): 223-7.

25. Vaquero $\mathrm{M}$, Gomez $\mathrm{P}$, Romero $\mathrm{M}$, Casal MJ. Investigation of biological risk in mycobacteriology laboratories: a multicentre study. Int J Tuberc Lung Dis 2003; 7(9): 879-85.

26. Morgan AP. Guide to Infection Control In The Healthcare Setting Laboratory Areas. Editor: Gonzalo Bearman. International Society for Infectious Diseases. Chapter last updated: April 2018 (https://isid.org/ guide/infectionprevention/laboratory/). Erişim Tarihi: 10.10.2019.

27. Tıbbi Laboratuvarlar Yönetmeliği. Resmî Gazete, 9 Ekim 2013, Sayı: 28790 https://www.resmigazete.gov.tr/ eskiler/2013/10/20131009-11.htm. Erişim Tarihi: 10.10.2019.

28. https://www.ailevecalisma.gov.tr/medias/11455/ipc_2019.xls. Erişim Tarihi: 10.10.2019.

29. Omokhodion FO. Health and safety of laboratory science students in Ibadan, Nigeria. JR Soc Health 2002; 122(2): 118-21.

30. Sayın Kutlu S, Kutlu M, Ergönül O, Akalın S, Güven T, Demiroğlu YZ, et al. Laboratory-acquired brucellosis in Turkey. J Hosp Infect 2012; 80(4): 326-30.

31. Akbaş E, Buyurgan V. Bildirimi Zorunlu Bulaşıcı Hastalıklar İçin Klinik Mikrobiyoloji Laboratuvarlarının Tanı Kapasitelerinin Değerlendirilmesi: Bir Anket Çalışması. XXXII. Türk Mikrobiyoloji Kongresi, 12-16 Eylül 2006, Antalya.

32. Isouard G. Biosafety practices in pathology laboratories. Aust Health Rev 1988;11(2):122-9. 